\title{
Adaptation to long-term forced saline consumption during postweaning in rats*
}

\author{
JOHN W. WRIGHT $\dagger$ \\ Fordham University, Bronx, New York 10458
}

\begin{abstract}
Earlier reports have established that rats exhibit a free-choice salt preference in excess of that needed for normal body maintenance. Young rats maintained on a high-sodium food diet evidence serum hyponatremia, as do mature rats provided both tap water and an isotonic saline solution. The present investigation tested the hypothesis that introduction of long-term formed saline consumption following weaning may encourage physiological adaptation, preventing the abnormal serum electrolyte levels previously noted. The results substantiate this hypothesis and also indicate a decrease in body weight minus gut and increase in relative heart weight in those animals maintained on hypertonic saline.
\end{abstract}

The phenomenon of saline consumption in excess of that needed for normal body maintenance appears to be primarily taste determined in rats (Finger \& Mook, 1971). When presented a choice between isotonic saline and water, rats prefer the saline solution if food is present (Bare, 1949; Hsiao, 1970; Weiner \& Stellar, 1951). Recently, there has been a proliferation of work relating nervous system damage with changes in sodium preference (Finger \& Mook, 1971); however, comparably little systematic data have been collected concerning serum electrolyte changes resulting from either brief or long-term saline consumption. There are discrepancies in the tangential data that have been reported. For example, Nelson (1947) has indicated that rats given prolonged free choice between water and isotonic saline ingest saline to such excess that signs of chronic sodium overloading may appear. And Adolph (1943) has shown that rats forced to consume sea water lose weight at a somewhat slower rate than do rats totally water deprived, and that they survive for 7 to 26 days. Other reports of forced consumption of moderately hypertonic saline solutions $(1.5 \%-2.5 \%)$ have also indicated detrimental consequences, e.g., hypertension (Sapirstein et al, 1950) accompanied by hypertrophy of the left ventricle of the heart (Green et al, 1948) and hypertrophy of the kidneys (Binet et al, 1951). There has been difficulty in replicating hypertension with forced consumption of a $2 \% \mathrm{NaCl}$ solution in rats (Jelinek et al, 1966). Serum electrolyte deviations were not monitored in these investigations.

Reports concerned with serum deviations have established that mature rats (120 days of age) provided a

*This investigation was supported in part by Fordham University Faculty Research Grant NSF GU-3554. The author would like to thank Henry R. Askew, of Fordham University, for comments and critical reading of the manuscript. and Drs. Hellerman and Riklan and Mary Ruggiero, of St. arnabas Hospital, and Alex and Timothy Wright for technical assistance rendered during the study.

$\div$ Reprint requests may be sent to John W. Wright, Department of Psychology, Fordham L'niversity, Bronx, New York 10458. choice between tap water and an isotonic saline solution evidence serum hyponatremia (Wright, 1973a). A similar decline in serum sodium level has been observed in young rats (28.35 days of age) maintained on a high-sodium food diet (French \& Manery, 1964). The present investigation examines the effects of long-term saline consumption upon serum electrolyte levels, and heart and kidney weights. Earlier findings would predict the occurrence of serum hyponatremia, however, during weaning there is maturation of homeostatic mechanisms concerned with water and salt regulation which allow the young rat independence from its mother (Jelinek, 1963). It is reasoned that the introduction of forced saline solution intake during this physiologically crucial period may encourage appropriate adaptation, thus preventing the abnormal serum electrolyte levels previously noted.

\section{METHODS}

\section{Subjects}

Twenty-four experimentally naive male albino Holtzman rats, approximately 30 days of age $(45-70 \mathrm{~g})$, were maintained, four animals per group cage, under constant illumination at a room temperature of $23^{\circ}-24^{\circ} \mathrm{C}$.

\section{Apparatus and Procedure}

The animals were assigned randomly to one of three groups, eight animals per group, a tap water control group, a second group provided $0.9 \% \mathrm{NaCl}$ solution, and a third group given $1.5 \%$ saline. The animals were retained in the group cages for a period of 100 days, and in addition to the assigned fluids were provided Wayne Mouse Breeder Blox (content: $0.42 \% \mathrm{Na}, 0.77 \% \mathrm{~K}$ ) ad lib. Group body weights and fluid consumptions were determined once daily between 0800 and $0900 \mathrm{~h}$. At the conclusion of this period, the animals ( 130 days of age) were adapted to unit metabolism cages (Acme Metal Products) under constant light for 3 days and were provided powdered Wayne Mouse Breeder Blox and the previously assigned fluids ad lib. Following this adaptation period, 7 days of metabolic measurements ensued. Body weight, food, and fluid consumptions were determined once daily between 0800 and $0900 \mathrm{~h}$ for each animal. Urine volume excretion was also 
Table 1

Mean Serum Na, K. Protein, Hematocrit, and Estimated Plasma Volume Changes for Each Experimental Group

\begin{tabular}{lccccc}
\hline $\begin{array}{c}\text { Experi- } \\
\text { mental } \\
\text { Group }\end{array}$ & $\begin{array}{c}\text { Serum Na } \\
(\mathrm{mEq} / \mathrm{L})\end{array}$ & $\begin{array}{c}\text { Serum K } \\
(\mathrm{mEq} / \mathrm{L})\end{array}$ & $\begin{array}{c}\text { Protein } \\
(\mathrm{g} / 100 \mathrm{ml})\end{array}$ & $\begin{array}{c}\text { Hematocrit } \\
(\text { Percent RBC) }\end{array}$ & $\begin{array}{c}\text { Plasma } \\
\text { Volume* } \\
(\mathrm{ml} / 100 \mathrm{~g})\end{array}$ \\
\hline Tap Water & $146.6 \pm 0.5 \div$ & $5.27 \pm 0.17$ & $7.1 \pm 0.2$ & $45.1 \pm 0.6$ & $3.40 \pm 0.17$ \\
$0.9 \% \mathrm{NaCl}$ & $147.6 \pm 0.4$ & $4.98 \pm 0.29$ & $6.9 \pm 0.1$ & $45.0 \pm 0.5$ & $3.41 \pm 0.16$ \\
$1.5 \mathrm{c} \mathrm{NaCl}^{\mathrm{N}}$ & $147.7 \pm 1.0$ & $4.82 \pm 0.17$ & $7.0 \pm 0.1$ & $45.0 \pm 0.5$ & $3.41 \pm 0.14$ \\
\hline
\end{tabular}

*Derived from Kutscher's (1971) regression equation, $P V=6.74-0.074$ (Hct)

tMean \pm standard error

measured and a sample was retained from each $\mathrm{S}$ and analyzed for osmolality level (Osmette. Precision Systems). Measurement errors of absolute metabolic intake and output values due to spillage were reduced by requiring the $S$ s to protrude their mouths outside their cages in order to obtain water from the cylinders. Thus. when spillage occurred, the water did not contaminate the urine samples, and paper slips under the cylinders indicated a very minimal magnitude of spillage. Urine evaporation was reduced by collecting the samples under mineral oil. and the funnels were cleaned. rinsed in distilled water. and dried immediately following the morning reading period of each day.

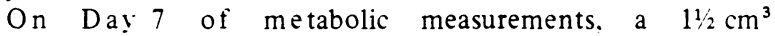
heart-puncture blood sample was taken from each animal under light ether anesthesia between 0900 and $1230 \mathrm{~h}$. The serium samples were centrifuged at $3.300 \mathrm{rpm}$ for $3 \mathrm{~min}$. A portion of the retained serum was immediately analyzed for protein level in a refractometer (American Optical Company, Model 10402 TS meter). The remaining serum was utilized for determination of sodium and potassium concentrations by flame photometry (Instrumentation Laboratories. Model 143). In addition. two hemato otit samples per animal were prepared and certrifuged ing heparinized capillary tubes $(1.5-2.0 \mathrm{~mm}$ i.d. $75 \mathrm{~mm}$ long) at $11.500 \mathrm{rpm}$ for $5 \mathrm{~min}$ and were immediately read. A detailed description of the blood sampling procedure may be found in Wright (1973b). All animals were subsequently sacrificed by ether overdose. and heart and kidney weights were measured. Relative organ weights were determined with respect to total body weight minus the gut. The gut was excluded to eliminate deriations in content between animals.

\section{RESULTS}

The mean \pm standard error (SE) food consumption of the tap water group (Group 1) during the week in metabolism cages was $18.9 \pm 0.3 \mathrm{~g} /$ day the $0.9 \% \mathrm{NaCl}$ group (Group 2) ate $16.2 \pm 0.4 \mathrm{~g}$, and the $1.5 \% \mathrm{NaCl}$ group (Group 3), $13.3 \pm 0.5 \mathrm{~g}$. These group mean values were significantly different $(F=50.1, \mathrm{df}=2 / 21$, $\mathrm{p}<.001$; two-factor mixed ANOVA with repeated measures on one factor, Bruning \& Kintz, 1968). Mean \pm SE fluid intake for Groups 1-3 were $29.5 \pm 0.8$, $59.1 \pm 4.3$, and $81.0 \pm 3.5 \mathrm{ml} /$ day, respectively, and they were significantly different $(F=84.5, \mathrm{df}=2 / 21$, $\mathrm{p}<.001)$. Urine osmolality for Groups 1.3 during this week were $1,461 \pm 18,887 \pm 11$, and $725 \pm 8 \mathrm{mOsm} / \mathrm{L}$, also different $(\mathrm{F}=64.7, \mathrm{df}=2 / 21, \mathrm{p}<.001)$. The mean \pm SE body weights for Groups 1-3 during this week were $381.5 \pm 2.6,375.7 \pm 4.2$, and $341.4 \pm 4.2 \mathrm{~g}$, respectively $(\mathrm{F}=35.7, \mathrm{df}=2 / 21, \mathrm{p}<.001)$. Groups 1 and 2 did not differ; however, both weighed significantly more than Group 3 (Scheffé, $\mathrm{p}<.05$ ).
The results of the blood samples taken on the 7 th day of the week are presented in Table 1 . The mean serum sodium, potassium, and protein levels did not differ $(\mathrm{F}=$ $1.16,1.40$, and 0.33 , respectively, $\mathrm{df}=2 / 21 . \mathrm{p}>.10$ : simple randomized design). Nor were the hematocrit ratio values and estimated plasma volumes significantly different $(F=0.22$ and 0.18 , respectively, $\mathrm{df}=2 / 21$, $\mathrm{p}>.10)$.

Organ and body weights for each group are provided in Table 2. Body weight minus gut revealed significant differences between the groups $(F=5.2, \mathrm{df}=2 / 21$, $p<.05)$. There were nonsignificant differences between Groups 1 and 2; however, both differed from Group 3 (Scheffé, $\mathrm{p}<.05$ ). Neither the absolute nor the relative kidney weights were different, comparing the groups $(\mathrm{F}$ $=0.66$ and 0.31 , respectively, $\mathrm{df}=2 / 21, \mathrm{p}>.10)$. The absolute heart weights were also not different $(F=1.01$, $d f=2 / 21, p>10)$, but Group 3's relative heart weight was significantly greater than those of Groups 1 and 2 , which did not differ (Scheffé, $\mathrm{p}<.05)$.

\section{DISCUSSION}

Previous reports concerned with deviations in serum electrolytes accompanying short-term exposure to a high-sodium food diet (French \& Manery, 1964) or an isotonic saline solution (Wright, 1973a) have noted serum hyponatremia ranging from 7 to $10 \mathrm{mEq} / \mathrm{L}$ below control values with no apparent change in estimated plasma volume. The present investigation failed to indicate similar changes in serum electrolytes with forced long-term consumption of an isotonic or hypertonic saline solution. Of additional significance was the finding that estimated plasma volume remained stable in accordance with earlier findings. Nor did the protein levels of the three groups differ, a second frequently utilized estimator of plasma volume (Hatton \& Bennett, 1970). There is a discrepancy between the present experimental design and that employed earlier (Wright, 1973a) at which time mature animals were provided a free choice between ad lib tap water and $0.87 \%$ saline. Comparison of the data does seem justified, for in each instance there was sodium consumption in excess of that needed for normal body maintenance.

Concerning the measurements of body and organ 
Table 2

Organ and Body Weights of the Three Groups Tested

\begin{tabular}{lllll}
\hline $\begin{array}{l}\text { Experimen- } \\
\text { tal Group }\end{array}$ & $\mathrm{N}$ & $\begin{array}{c}\text { Body Weight } \\
\text {-Gut* }\end{array}$ & Kidneys & Heart \\
\hline Tap Water & 8 & $361.1 \pm 7.1 * *$ & $3.96 \pm 0.09(1.10 \pm 0.03) \div$ & $2.14 \pm 0.05$ \\
$0.9 \% \mathrm{NaCl}$ & 8 & $352.8 \pm 8.3$ & $3.92 \pm 0.13(1.11 \pm 0.05)$ & $2.06 \pm 0.04(0.58 \pm 0.02)$ \\
$1.5 \% \mathrm{NaCl}$ & 8 & $324.2 \pm 10.6$ & $3.77 \pm 0.15(1.16 \pm 0.02)$ & $2.18 \pm 0.07(0.67 \pm 0.01)$ \\
\hline
\end{tabular}

${ }^{*}$ Total body weight without gut $\quad{ }^{* *}$ Mean \pm standard error in grams $\quad$ tRelative organ weight $=\frac{\text { organ weight }}{\text { body weight }- \text { gut }} \times 100$

weights, there appeared to be retardation of body growth in those animals placed on hypertonic saline. And the indication that there was no change in absolute heart weight but significant increases in relative heart weight for animals placed on hypertonic saline agrees with Jelinek et al (1966).

With reference to the saline solutions presently tested and the blood constituents measured, it seems reasonable to conclude that postweaning physiological adaptation to forced saline consumption does occur. The evolutionary significance of such an adaptive mechanism may lie in the varying salt content of drinking water found in the natural habitat. Presumably, the rat's capability to adjust to such environmental deviations in water content would be exceedingly important immediately following weaning. This flexibility appears to diminish with maturation. The precise nature of the regulatory mechanisms underlying this adaptation remain imperfectly understood and in need of further investigation.

\section{REFERENCES}

Adolph, E. F. Do rats thrive when drinking sea water? American Journal of Physiology. 1943, 140, 25-32.

Bare, J. K. The specific hunger for sodium chloride in normal and adrenalectomized white rats. Journal of Comparative \& Physiological Psychology. 1949, 42, 242-253.

Binet, L., Dejours, P.. \& Lacaisse, A. Etude du functionment du rein hypertophié par la surcharge alimentaire en cristalloides chez le rat. Journal of Physiology. Paris, 1951, 43, 365-373.

Bruning, J. L., \& Kintz, B. L. Computational handbook of statistics. Glenview, Ill: Scott, Foresman, 1968.

Finger, F. W., \& Mook, D. G. Basic drives. Annual Review of Psychology, 1971, 22, 1-38.

French, I. W., \& Manery, J. F. The effect of aldosterone on electrolytes in muscle, kidney cortex, and serum. Canadian
Journal of Biochemistry, 1964, 42, 1459-1476.

Green, D. M., Coleman, D. H., \& McCabe, M. Mechanismus of desoxycorticosterons action. II. Relation of sodium chloride to fluid exchange. Pressor effects and survival. American Journal of Physiology, 1948, 154, 465-474.

Hatton, G. I., \& Bennett, C. T. Satiation of thirst and termination of drinking: Roles of plasma osmolality and absorption. Physiology \& Behavior, 1970, 5, 479-487.

Hsiao, S. Feeding-drinking interaction: Intake of salted food and saline solutions by rats. Canadian Journal of Psychology, $1970,24,8-14$.

Jelinek, J. Changes in the distribution of water in the body following administration of a hypertonic $\mathrm{NaCl}$ solution and during water deprivation in rats during their postnatal development. Physiologia Bohemoslovaca, 1963, 12, 435-442.

Jelinek, J., Kraus, M., \& Musilova, H. Adaptation of rats of different ages to forced intake of a $2 \% \mathrm{NaCl}$ solution without the occurrence of salt hypertension. Physiologia Bohemoslovaca, 1966, 15, 137-147.

Kutscher, C. L. Hematocrit, plasma osmolality, and plasma protein concentration as estimators of plasma volume in hooded rats during food and water deprivation. Physiology \& Behavior, 1971, 7, 283-285.

Nelson, D. Do rats select more sodium than they need? Federation Proceedings, 1947, 6, 169.

Sapirstein, L. A., Brandt, W., \& Drury, D. R. Production of hypertension in the rat by substituting hypertonic sodium chloride solutions for drinking water. Proceedings, Society of Experimental Biology \& Medicine, 1950, 73, 82-85.

Weiner, I. H., \& Stellar, E. Salt preference of the rat determined by a single stimulus method. Journal of Comparative \& Physiological Psychology, 1951, 44, 394-401.

Wright, J. W. Effects of saline consumption and adrenalectomy on water balance in rats. Behavioral Biology, 1973a, 8, 291-296.

Wright, J. W. The effects of a heart puncture blood sample upon body water maintenance in rats. Physiology \& Behavior, $1973 \mathrm{~b}$, in press.

(Received for publication November 14, 1972; revision received January 18,1973 .) 